Original Research Paper

\title{
Biochemical Composition and Nutraceutical Perspectives Red Sea Seaweeds
}

\author{
Eman A. Alwaleed \\ Department of Botany, Faculty of Science, South Valley University, Qena, Egypt
}

\author{
Article history \\ Received: 17-12-2019 \\ Revised: 14-01-2020 \\ Accepted: 22-01-2020 \\ Tel: +01068681431 \\ Fax: + 20965211279 \\ Email: Eme_biologist@sci.svu.edu.eg
}

\begin{abstract}
Seaweeds are marketed as "nutraceuticals" owing to their highly bioactive ingredients as well as food supplements in order to relinquish physiological conditions and resist diseases. In the current study, the biochemical compositions (total protein, carbohydrate, lipid, fatty acids, amino acid, minerals and dietary fibers) of the seaweeds Caulerpa racemosa, Digenea simplex, Sargassum polycystum and Cystoseria myrica were evaluated. Digenea simplex alga has the highest content of protein, while $C$. racemosa is rich in lipid. Highly concentrations of carbohydrates and dietary fibers were detected in $S$. polycystum and $C$. myrica. However, C. myrica contains large amount of amino acids. This research focused on the role of chemical composition of seaweeds in consumption as food and valuable medicinal products.
\end{abstract}

Keywords: Carbohydrates, Dietary Fibers, Lipid, Protein and Seaweeds

\section{Introduction}

Marine algae are used since ancient times as food fodder and fertilizer and as supply of healthful medication (Rupapara, 2017). They need expanded importance as meditative sources due to their high healing, antimicrobial and antioxidant activities (Fan et al., 2014).

Fan et al. (2014; Ismail, 2017; Ismail et al., 2017; 2016) illustrated the vital role of seaweeds for human and animal health and consumed as daily diets in orient countries (El-Shafay, 2014).

Seaweeds are referred to a valuable source of protein, elements, dietary fibers, vitamins, essential amino acids and they contain various polysaccharides, including alginate, cellulose and laminarin (Ismail et al., 2016; Lyu et al., 2016). Sargassum are exceptional dietary sources of proteins, carbohydrates, trace minerals and other bioactive compounds (Cabrita et al., 2016; Telles et al., 2018). Caulerpa sp. is one of the favored species due to its grass-green in color, succulent texture and usually consumed in the form of fresh vegetable (Ratana-arporn and Chirapart, 2006). These seaweeds are frequently reported as food, animal feeds and fertilizers (El Shafay et al., 2016; Kolanjinathan and Saranraj, 2014).

Ortiz et al. (2006) stated that the species, maturity, environmental growth conditions and seasonal period influenced on the nutrient compositions of seaweeds. Owing to the accumulative world population, the concern for food and energy is levitation the necessity for numerous, sustainable sources for food commodities (Janssen et al., 2018).

Most of the conservational restrictions diverge owing to season and the variations in ecological conditions will stimulate or inhibit the biosynthesis of many nutrients (Hernández et al., 1995; Manivannan et al., 2009; Zubia et al., 2019) They are more nutritious and rich in vitamins and minerals than the other food. The nutritional properties of seaweeds are poorly identified and usually are assessed from the chemical composition (Ismail, 2017).

The most necessary biochemical components of algae are protein, carbohydrates and Lipids. fatty acids of microalgae and Seaweeds from the Red Sea have limited studies in. Macroalgae biomasses can accumulation enormous quantities of oil which can be demoralized for the assembly of biodiesel especially bioethanol (John and Anisha, 2011). The species of algae performance a vital protagonist on alteration the protein content (Ratana-arporn and Chirapart, 2006).

Specific suggestions counsel that fatty acids and sterol composition could also be helpful for taxonomic purposes (El-Shafay, 2014; Herbreteau et al., 1997). Accumulation of olefinic fatty acids was observed in Rhodophyta, principally arachidonic and eicosapentaenoic acids. Alternative luxuriant fatty acids during this category are palmitic and oleic acids. The amino acids composition pronounced variations were 
discovered in protein and amino acids between different algal specimens (MacArtain et al., 2007; Qasim, 1991).

Marine algae have lots of vital nutrients, fundamentally trace elements and a number of other bioactive substances. That clarifies why nowadays seaweeds are deliberated as the food supplement for twenty-one century as supply for first proteins, lipids, polysaccharides, mineral, vitamins and enzymes. Thus, the aims of this work were to determine the nutritional compositions of Caulerpa racemosa, Digenea simplex, Sargassum polycystum and Cystoseria myrica. This paper presented data on the nutritional and chemical composition of Caulerpa racemosa, Digenea simplex, Sargassum polycystum and Cystoseria myrica; i.e., proximate composition, protein, carbohydrate, fiber, lipid, fatty acid and amino acid contents. This work also reported a comparative evaluation of nutritive values of these seaweeds with those of some other seaweeds and some locally consumed vegetables. The potential of both seaweeds as sources of food nutrients was discussed.

\section{Materials and Methods}

\section{Collection of Seaweeds}

Samples used for the present study was collected from Hurghada Red Sea coastal, Egypt. The study was conducted in March 2017, These species classified into three categories chlorophyta (Caulerpa racemosa), Phaeophyta (Sargassum polycystum and Cystoseria myrica) and Rhodophyta species (Digenea simplex) (Fig. 1). The collected sample was washed thoroughly with sea water to remove sand particles, impurities and epiphytes (Sasikala et al., 2016).

\section{Preparation of Seaweed}

The samples were washed with tap water to remove salts and it was finally washed with distilled water. The

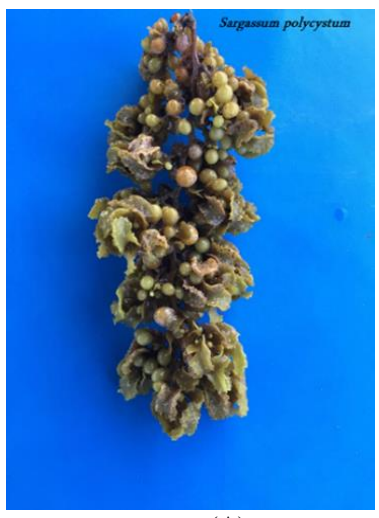

(A)

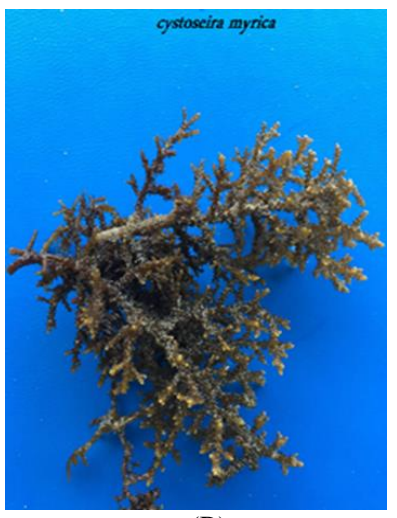

(B)

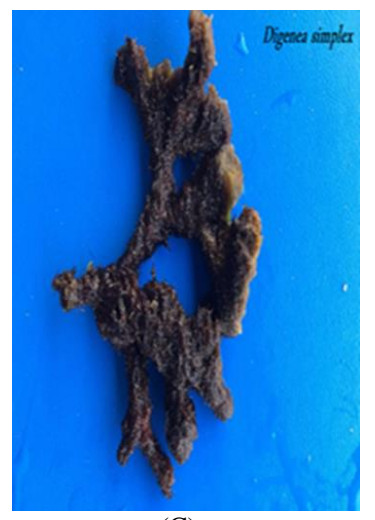

(C)

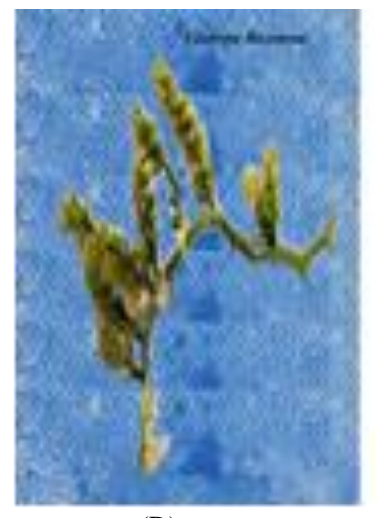

(D)

Fig. 1:A and B: The brown seaweed species Sargassum polycystum and Cystoseria myrica, C: The red seaweed species Digenea simplex and D: The green seaweed species Caulerpa racemosa 


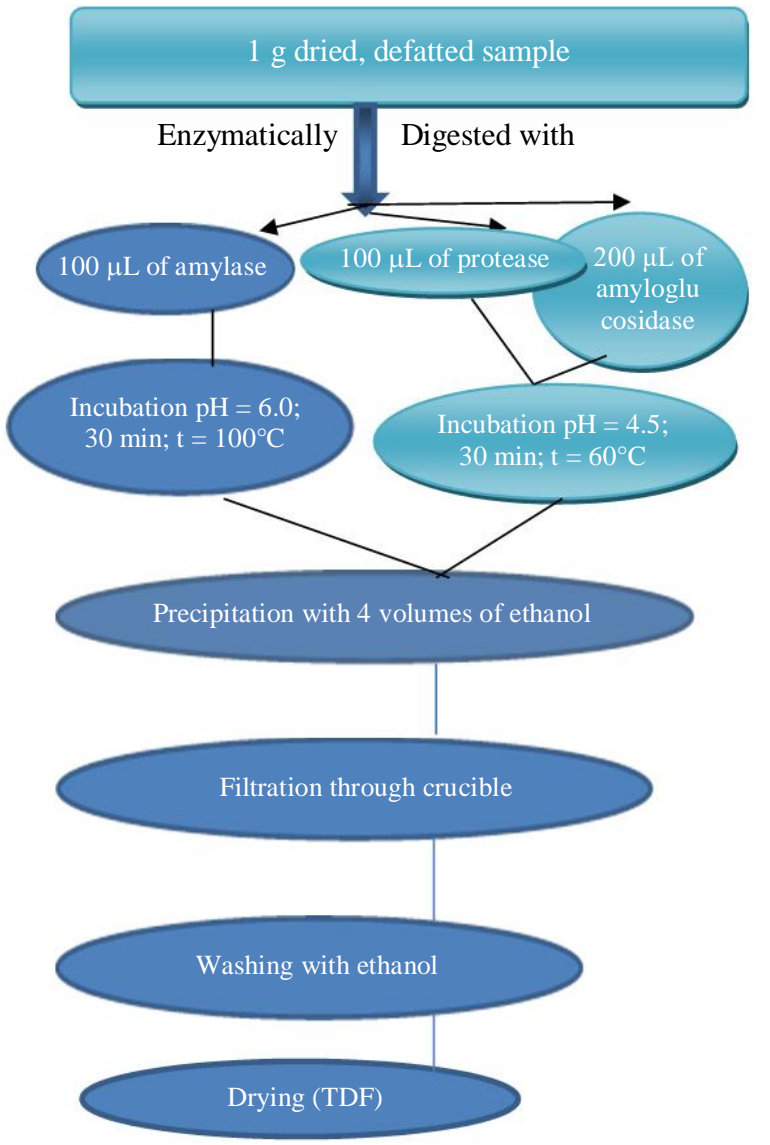

Fig. 2: The procedure of TDF determined

\section{Fatty Acid Extraction and Analysis}

Fatty acids were analyzed for four individuals of each collected sample. A direct transesterification method, adapted from (Cohen et al., 1988) and (Rodríguez-Ruiz et al., 1998), was used to simultaneously extract and esterify the fatty acids to Fatty Acid Methyl Esters (FAMEs) for analysis by GC-MS. This method was performed at the national center research.

Determination of the total amino acids was performed by (Walker et al., 1996) protocol at the National Center of Radiation Research and Technology, Cairo, Egypt.

\section{Statistical Analysis}

The biochemical components (proteins, carbohydrates, lipids and Mineral composition) were obtained as the mean of three replicates \pm SE (standard errors). The mean values were implemented by Duncan's Multiple Range Test (DMRT) at the significant level of $\mathrm{p}<0.05$ using SPSS (version 21.0).

\section{Results}

The superlative vital organic ingredients of algae are protein, carbohydrate and lipid. Protein content of marine algae specimen differs between $5.0 \%$ and $21.0 \%$ of Dry Weight, reliant to a large extent on the phylum, species, geographical origin and time of harvest. Generally, it's low for brown seaweeds (5.85 and $10.35 \%$ dry weight), moderate for green algae (17.81\% of dry weight) and high for red seaweeds (maximum $21.14 \%$ dry weight). The relationship between all algal species was nonsignificant (at $\mathrm{p}<0.05$ ). The mandatory energy for respiration and other metabolic processes was provided by carbohydrate so it's considered the most important component for metabolism. Variations in carbohydrate content at the various studied macroalgae were determined throughout this study. The results exhibited that, the four studied species have a very high concentration of carbohydrates extended from $190.01 \%$ in Sargassum to $78.7 \%$ in $C$. myrica and $49.27 \%$ in $C$. racemosa and about the same content in D. simplex $42.40 \%$ ). Sargassum (brown seaweeds) gave the highest carbohydrate accumulation. Adaptation to statistical analyses there was significant relation between $S$. polycystum, C. racemosa and $D$. simplex, however the other relations was insignificant.

The total lipid contents within the investigated seaweed species were comparatively low (Fig. 3), the highest value was initiating in C. racemosa $4.45 \%$ and the lowest was recorded in $S$. polycystum.

$S$. polycystum and $C$. myrica (brown algae) when compared with other nominated seaweeds have slightly more fiber than D. simplex (red algae) and C. racemosa (green algae) $(10.55 \%$ and $5.93 \%)$ respectively Table 1. The brown seaweeds considered also rich in the soluble and insoluble fiber (C. myrica 6.58 and 31.66) when compared with other seaweeds.

The mineral contents of seaweeds as well as the values reported in local vegetables and selected edible seaweeds were shown in Table 2. The Dietary Recommended Intake (DRI) for Thai male and female of age 19-50 years recommended by Nutrition Division (2003) were also presented in Table 2. It was clearly shown that both seaweeds contained considerably high amount of minerals.

Sodium content in four seaweed species varied from 9.33 to $23.57 \%$ being maximum in $C$. racemosa; however, Calcium content was high in $C$. myrica than the other three species (Table 1) Potassium content exhibited a little variation in different seaweeds, but the Magnesium level was more or less similar. Lead concentration was minimum in all the seaweeds.

Ion quotient $\mathrm{Ca}+\mathrm{Na} / \mathrm{Mg}+\mathrm{K}$ this molar ratio was calculated (Table 2) to be $0.20,0.99,0.99$ and 0.79 for D. simplex, S. polycystum, C. racemosa and C. myrica, respectively. These consequences infer that exhausting seaweed species in foods can decline this range in human body and decline associated diseases such as hypertension and heart disease. Subsequently, these seaweed species were high superiority and safety and might be used in the field of nutrition. Seaweeds are 
presently deliberated to be a favorable source of fatty acids (FA). On the other hand, FA content and their composition can differ significantly dependent on species and environmental conditions. As detected from Table 3, bio-paraffinic fatty acids (saturated fatty acids) were the focal types present in the all studied species. S. polycystum contain the highest percentage $75.52 \%$ of the total saturated fatty acids, while, species $C$. myrica contain the lowest content of total saturated fatty acids.
C16:0 was the most bio-paraffinic fatty acid (saturated fatty acid) amongst the all studied species. The higher ratio was observed in species $C$. racemosa; the studied species have low concentration of olefinic fatty acids. The lowest accumulation of total unsaturated fatty acids was appeared in $C$. myrica and $C$. racemosa. Green alga (C. racemosa) was characterized by the present of Linoleic $(\omega 6)(\mathrm{C} 18: 2)$.

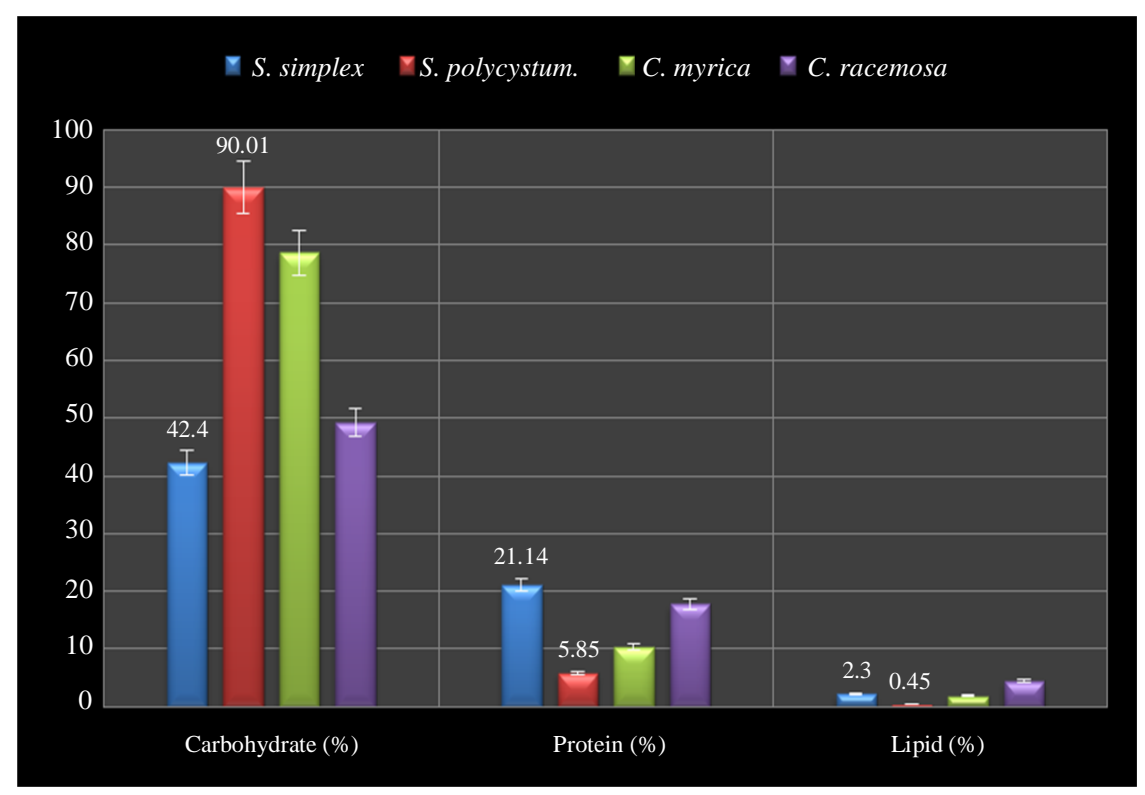

Fig. 3: The mean contents of lipid, protein and carbohydrate in the algal species Data Represent Means and Standard Errors (Error Bars) of Three Biological Replicates

Table 1: Fiber content of Seaweeds species (g/100 wet weight) compared to dietary reference intake (g/day)

\begin{tabular}{lllc}
\hline Seaweeds species & Total fiber & Soluble fiber & Insoluble fiber \\
\hline DRI ${ }_{\mathrm{b}}$ Male and female & $25 \mathrm{~g} /$ day & & \\
Digenea simplex & 10.55 & 7.98 & 2.57 \\
Caulerpa racemosa & 5.93 & 2.38 & 3.55 \\
Sargassum polycystum & 33.95 & 5.68 & 28.27 \\
Cystoseria. myrica & 38.24 & 6.58 & 31.66 \\
\hline
\end{tabular}

${ }^{\mathrm{b}}$ Dietary Reference Intake: The amount recommended for consume daily for Thai adult of age19-50 years (Ivanovitch et al., 2014)

Table 2: Mineral compositions (mg/100g Dwt.) of seaweed species compared to Dietary Reference intake(mg/day)

\begin{tabular}{|c|c|c|c|c|c|c|}
\hline Minerals & $\begin{array}{l}\text { Digenea } \\
\text { simplex }\end{array}$ & $\begin{array}{l}\text { Caulerpa } \\
\text { racemosa }\end{array}$ & $\begin{array}{l}\text { Sargassum } \\
\text { polycystum }\end{array}$ & $\begin{array}{l}\text { Cystoseria } \\
\text { myrica }\end{array}$ & $\begin{array}{l}\text { DRI b } \\
\text { male }\end{array}$ & $\begin{array}{l}\text { DRI b } \\
\text { female }\end{array}$ \\
\hline Sodium & $1198 \pm 1.15^{\mathrm{a}}$ & $2357 \pm 1.73^{b}$ & $933 \pm 0.58^{\mathrm{a}}$ & $1280 \pm 1.00^{\mathrm{a}}$ & $475-1450$ & $400-1200$ \\
\hline Calcium & $432 \pm 0.58^{\mathrm{a}}$ & $1255 \pm 1.43^{\mathrm{b}}$ & $1444 \pm 2.30^{\mathrm{b}}$ & $1550 \pm 0.29^{b}$ & 800 & 800 \\
\hline Phosphorus & $368 \pm 0.4^{\mathrm{ab}}$ & $703 \pm 0.4^{\mathrm{b}}$ & $212 \pm 0.3^{c}$ & $415 \pm 0.3^{\mathrm{a}}$ & 700 & 700 \\
\hline Magnesium & $398 \pm 0.58^{\mathrm{a}}$ & $767 \pm 1.13^{\mathrm{ab}}$ & $560 \pm 0.59^{\mathrm{b}}$ & $675 \pm 1.15^{\mathrm{ab}}$ & $310-320$ & $250-260$ \\
\hline Potassium & $7744 \pm 1.40^{c}$ & $2875 \pm 1.14^{\mathrm{b}}$ & $1832 \pm 0.18^{a}$ & $2890 \pm 0.06^{\mathrm{b}}$ & $2450-4100$ & $2050-3400$ \\
\hline Lead & $0.01 \pm 0.01^{\mathrm{a}}$ & $0.03 \pm 0.01^{\mathrm{b}}$ & NR & $0.06 \pm 0.00^{\mathrm{a}}$ & NR & NR \\
\hline $\mathrm{Na} / \mathrm{K}$ Ratio & $0.15 \pm 0.03^{\mathrm{a}}$ & $0.82 \pm 0.07^{c}$ & $0.51 \pm 0.00^{\mathrm{b}}$ & $0.44 \pm 0.02^{\mathrm{b}}$ & NR & NR \\
\hline Ion quotient ratio (inmoles) & & & & & & \\
\hline $\mathrm{Ca}+\mathrm{Na} / \mathrm{Mg}+\mathrm{K}$ & $0.20 \pm 0.58^{\mathrm{a}}$ & $0.99 \pm 0.32^{\mathrm{b}}$ & $0.99 \pm 0.31^{\mathrm{b}}$ & $0.79 \pm 0.06^{\mathrm{ab}}$ & NR & NR \\
\hline
\end{tabular}

${ }^{\mathrm{b}}$ Dietary Reference Intake: the amount recommended for consume daily for Thai adult of age19-50 years (Ivanovitch et al., 2014) Data represent means and standard errors (error bars) of three biological replicates. Different letters indicate significant difference $(\mathrm{p}<\mathrm{t} 0.05)$. NR: Not Reported 
Table 3: Fatty acid contents (mg/g sample) and profiles (g/100g fatty acids) of the four studied

\begin{tabular}{|c|c|c|c|c|c|c|c|}
\hline Fatty acids & $\begin{array}{l}\text { Digenea } \\
\text { simplex }\end{array}$ & $\begin{array}{l}\text { Sargassum } \\
\text { polycystum }\end{array}$ & $\begin{array}{l}\text { Cystoseria } \\
\text { myrica }\end{array}$ & $\begin{array}{l}\text { Caulerpa } \\
\text { racemosa }\end{array}$ & Porphyra ${ }^{a}$ sp. & Palmaria ${ }^{a}$ sp. & $\begin{array}{l}\text { Gracillaria }^{b} \\
\text { changgi }\end{array}$ \\
\hline \multicolumn{8}{|l|}{ Saturated fatty acids (SFA) } \\
\hline Caprylic $(C 8: 0)$ & 2.154 & ND & 0.031 & ND & ND & ND & ND \\
\hline Pelargonic (C9:0) & 1.02 & ND & ND & ND & ND & ND & ND \\
\hline Capric (C10:0) & 2.24 & ND & 0.11 & ND & ND & ND & ND \\
\hline Lauric $(C 12: 0)$ & 4.01 & 1.51 & 0.68 & ND & ND & ND & ND \\
\hline Tetradecanoic (C13:0) & 1.99 & 4.02 & 4.34 & 4.93 & ND & ND & ND \\
\hline Palmitic (C16:0) & 14.02 & 21.40 & 26.37 & 38.11 & 63.19 & 45.44 & 22.0 \\
\hline Stearic (C18:0) & 1.83 & 6.37 & 3.89 & 2.01 & 1.23 & 1.28 & ND \\
\hline Arachidic $(C 20: 0)$ & 30.78 & 1.02 & 0.78 & 1.99 & ND & ND & ND \\
\hline Sum saturated fatty acids (SFAs) & 59.81 & 45.24 & 40.03 & 55.14 & 64.42 & 46.72 & 22.00 \\
\hline$\%$ to T. FA & 65.05 & 75.52 & 73.90 & 58.01 & & & \\
\hline \multicolumn{8}{|l|}{ Mono-unsaturated (MUFA) } \\
\hline Myristoleic (C14:1) & 3.70 & 2.90 & 3.07 & 3.08 & ND & ND & ND \\
\hline Palmitoleic (C16:1) & 6.50 & 2.82 & 1.83 & 3.95 & 6.22 & 5.26 & ND \\
\hline Oleic $(\omega 9)(C 18: 1)$ & .320 & 5.14 & 0.98 & 7.85 & 6.7 & 3.13 & 21.9 \\
\hline Eicosanoate (C20:1) & ND & ND & ND & ND & 4.7 & 0.20 & ND \\
\hline Sum & 15.26 & 12.41 & 7.70 & 19.98 & 17.62 & 8.59 & 21.9 \\
\hline$\%$ to T. FA & 16.60 & 20.72 & 14.21 & 21.02 & & & \\
\hline \multicolumn{8}{|l|}{ Poly-unsaturated (PUFA) } \\
\hline Linoleic $(\omega 6)(C 18: 2)$ & 6.52 & 0.50 & 5.65 & 8.93 & 1.17 & 0.69 & ND \\
\hline Linolenic ( $\omega 3)$ (C18:3) & 2.80 & .500 & 0.60 & 6.76 & 0.23 & 0.59 & ND \\
\hline Arachidonic $(\omega 6)(C 20: 4)$ & 2.90 & 1.02 & ND & 3.31 & 6.8 & 1.45 & ND \\
\hline Eicosapentaenoic ( $\omega 3)(C 20: 5)$ & 3.20 & 0.23 & 0.19 & 0.93 & 6.03 & 24.05 & 33.1 \\
\hline Sum & 15.42 & 2.25 & 6.44 & 19.93 & 14.23 & 26.78 & 33.1 \\
\hline$\%$ to T. FA & 16.77 & 3.76 & 11.89 & 20.97 & & & \\
\hline T. FA & 91.94 & 59.90 & 54.17 & 95.05 & & & \\
\hline
\end{tabular}

a(Sánchez-Machado et al., 2004)

b(Norziah and Ching, 2000) ND: Not Detected

Table 4: Amino acid compositions (g/100 g sample dry basis) and profiles (g/100 g amino acids) of the four studied seaweeds

\begin{tabular}{|c|c|c|c|c|c|c|}
\hline Amino Acids & $\begin{array}{l}\text { D. simplex } \\
\mathrm{g} / 100 \mathrm{~g} \\
\text { amino acids }\end{array}$ & $\begin{array}{l}\text { S. polycystum } \\
\mathrm{g} / 100 \mathrm{~g} \\
\text { amino acids }\end{array}$ & $\begin{array}{l}\text { C. myrica } \\
\mathrm{g} / 100 \mathrm{~g} \\
\text { amino acids }\end{array}$ & $\begin{array}{l}\text { C. racemose } \\
\mathrm{g} / 100 \mathrm{~g} \\
\text { amino acids }\end{array}$ & $\begin{array}{l}\text { Egg }{ }^{\mathrm{a}} \\
\mathrm{g} / 100 \mathrm{~g} \\
\text { amino acids }\end{array}$ & $\begin{array}{l}\text { Soya }^{\mathrm{a}} \\
\mathrm{g} / 100 \mathrm{~g} \\
\text { amino acids }\end{array}$ \\
\hline \multicolumn{7}{|l|}{ Non- Essential amino acids } \\
\hline Alanine & 2.40 & 4.25 & 6.7 & 4.71 & & \\
\hline Arginine & 2.34 & 3.13 & 5.04 & 4.66 & & \\
\hline Aspartic & 5.01 & 6.80 & 10.50 & 5.51 & & \\
\hline Cysteine & 1.88 & 0.25 & ND & 3.11 & & \\
\hline Glutamic & 7.50 & 5.15 & 6.20 & 5.50 & & \\
\hline Glycine & 1.87 & 3.45 & 3.00 & 4.81 & & \\
\hline Proline & .320 & 1.78 & 4.20 & 2.73 & & \\
\hline Serine & 2.80 & 4.54 & 6.60 & 4.74 & & \\
\hline Tyrosine & 4.40 & 2.09 & 2.50 & 2.70 & & \\
\hline Total non-essential amino acids & 28.52 & 31.44 & 44.74 & 40.47 & & \\
\hline \multicolumn{7}{|l|}{ Essential amino acids } \\
\hline Histidine & 0.86 & 2.23 & 2.40 & 3.76 & ND & ND \\
\hline Leucine & 5.70 & 4.95 & 6.98 & 6.54 & 8.60 & 7.60 \\
\hline Lysine & 6.50 & 4.11 & 6.76 & 7.88 & 7.00 & 6.10 \\
\hline Methionine & 4.87 & 2.77 & 1.81 & 5.92 & ND & ND \\
\hline Phenylalanine & 10.74 & 9.63 & 12.33 & 4.88 & 9.30 (+Tyr) & $8.40(+\mathrm{Tyr})$ \\
\hline Threonine & 7.52 & 5.71 & 6.96 & 7.66 & 4.70 & 4.10 \\
\hline Valine & 1.80 & 5.50 & 6.24 & 5.15 & 6.60 & 5.20 \\
\hline Tryptophan & ND & 0.63 & 0.59 & 0.96 & ND & ND \\
\hline Total essential amino acids & 40.78 & 40.08 & 52.41 & 49.18 & 41.60 & 36.50 \\
\hline Total amino acids & 70.30 & 68.52 & 97.15 & 89.65 & & \\
\hline
\end{tabular}

a (Galland-Irmouli et al., 1999)

ND: Not Detected

The amino acid contents of the four studied seaweeds are demonstrated in Table 4. The levels of altered essential amino acids ranged from 40.08 to 52.41 $\mathrm{mg} / 100 \mathrm{mg}$ DW. Both species were rich in phenylalanine, threonine and lysine. Their Non-Essential Amino Acids, namely alanine, arginine, aspartic acid, 
cysteine, glutamic acid, serine, proline, glycine and tyrosine ranged from 28.52 to $44.74 \mathrm{mg} / 100 \mathrm{mg} \mathrm{DW}$. Aspartic and glutamic acids in the four species are mandatory for the special flavor and taste.

The deliberate species presented distinctive high concentrations of essential amino acids; whereas nonessential amino acids contemporary with low concentration in the all studied species. The assessment of the amino acid composition of seaweeds with FAO and those of alternate food proteins permits us to evaluation the nourishing assessment of seaweed proteins. It's obvious that furthermost of the seaweeds appear to be able to provide by tolerable levels of total essential amino acids within the food request.

\section{Discussion}

The most vital organic chemistry constituents of algae are protein, carbohydrate and lipid (Fleurence et al., 2018; Omar et al., 2013).

A carbohydrate is that the main molecule symptoms that influence on a different physiological response in regulated genes in photosynthesis, metabolism and selfprotective retorts. There are variances in the accumulation and distribution of carbohydrates in the four studied macroalgae. In the contemporary investigation, the data of carbohydrates accumulation exposed three situation of the accumulation of carbohydrate were recorded among the four species of algae under studies as the following:

(1) Decrease in C. racemosa and about the same content in D. simplex $42.40 \%$

(2) Increased progressively in S. polycystum

(3) Moderate in C. myrica about $78.7 \%$.

Environmental factors and the method used to extraction the most vital role to alteration between species (Peinado et al., 2014).

Dhargalkar et al., 1980; Sobha et al., 2001 illustrated that maximum assessment of carbohydrate accumulation in Rhodophyceae members higher than in Phaeophyceae and Chlorophyceae members. In the current investigation, the contrastingly Phaeophyceae members showed high carbohydrate content than Rhodophyceae and Chlorophyceae members. The highest accumulation of carbohydrate in Phaeophyceae might be outstanding to higher phycocolloid content in their cell walls (Dhargalkar et al., 1980).

The all picture of protein in the four algae species revealed that the criteria of protein differ greatly among the different species of algae used for example:

1. Moderate for green algae (17.81\% of dry weight)

2. Low for brown seaweeds (5.85 and $10.35 \%$ dry weight)
3. High for red seaweeds (21.14 \% dry weight) among the different species of algae under studies

The association among all algal species was nonsignificant $(\mathrm{p}<0.05)$. These variances might be predictable as dissimilarities in the protein content of seaweeds can be accredited to species variances and seasonal effects (Fleurence et al., 2018).

The total lipid contents within the studied seaweed species were comparatively low (Fig. 3), the highest value was documented in C. racemosa $4.45 \%$ and the lowest value was recorded in $S$. polycystum. Typically, seaweeds don't seem to be virtuous source of lipid (Ratana-arporn and Chirapart, 2006) and the total lipid content was perpetually institute less than $4 \%$ (Herbreteau et al., 1997). These results are reinforced by the conclusions of (Shanmugam and Palpandi, 2008) in Sargassum wightii $(0.45 \%)$, in Caulerpa racemosa (7.56) and in red alga jania $(0.9 \%)$. The dissimilarities might are because of factors like climate and geography of development of the seaweed (Herbreteau et al., 1997).

These results refer that the brown algae rich in dietary fibers when compared with other seaweeds (McBean and Speckmann, 1988). Seaweeds can deliver up to $12.5 \%$ of a person's every day. This is relatively large amount when compared with other terrestrial foods.

It was evidently displayed that both seaweeds contained noticeably high amount of minerals. According to our results, these seaweeds may serve as food supplements to help meet the recommended daily adult intakes of some minerals.

Ion quotient $\mathrm{Ca}+\mathrm{Na} / \mathrm{Mg}+\mathrm{K}$ this molar ratio was premeditated (Table 1) to be 0.20, 0.99, 0.99 and 0.79 for $D$. simplex, $S$. polycystum, $C$. racemosa and $C$. myrica respectively. The ion quotient usually diverges between 2.5 and 4.0 in human body (Ismail, 2017; Ismail et al., 2017). These consequences infer that exhausting seaweed species in foods can reduction this range in human body and lessen allied ailments such as hypertension and heart ailment.

At this time seaweeds deliberated to be auspicious source of Fatty Acids (FA). Variations in fatty acid contents are owing to both environment and genetic differences (Sánchez-Machado et al., 2004). In this work, eighteen fatty acids were identified. As detected from Table 3, fatty acids were the principal in categories contemporary in the all investigated species. The fatty acid pattern of Caulerpa and Digenea was similar to that of Porphyra but higher in saturated fatty acid (stearic acid) and total unsaturated fatty acids and lower in saturated fatty acid palmitic acids.

Species D. simplex and $S$. polycystum contain the highest percentage of total fatty acids, while, $C$. myrica has the lowest content of total fatty acids. This result corresponds with (Shanmugam and Palpandi, 2008) who stated that the saturated fatty acids constituted $70.01 \%$ of 
the total fatty acids. As detected from Table 3, the unsaturated fatty acids present by nearly low concentration in the four investigated species (Ishakani, 2017). In the recent search species $C$. racemosa was branded by the highest amount of polyunsaturated fatty acids amongst the premeditated algae and it branded by the present of Linoleic ( $\omega 6)$ (C18:2). This discrepancy could be due to numerous aspects, allied result has been obtained (Ismail et al., 2016). Conferring to Nelson et al., 2002, total algae specimen lipid content accumulated through winter and spring and deteriorated in summer. Temperature deliberated the most important environmental factors that influenced on fatty acids cell membranes (Peng et al., 2015) wherever at low temperatures fatty acids contents escalation.

The nutritive assessment of food can be indomitable by the content, proportion and availability of its amino acids, predominantly for assessment of a new protein resource. The four species have large quantity of aspartic and glutamic acids that are blamable for the special flavor and taste. Related consequences have been acquired in prior investigations (Wong and Cheung, 2000).

The investigated species performed distinctive high concentrations of essential amino acids Table 4; whereas nonessential amino acids contemporary with low concentration within the all investigated species. These results match with (Ratana-arporn and Chirapart, 2006). The result indicated that seaweeds proteins were of high quality because the essential amino acids represented almost $40 \%$ of total amino acids and the essential amino acids profile were closed to those of egg and soya protein (Galland-Irmouli et al., 1999), except for $C$. myrica and $C$. racemosa the essential amino acids profile were higher than those of egg and soya protein.

Hence, results of the contemporary study determine that seaweeds are a prospective health food in human diets and in the food industry as a foundation of constituents with high nutritional worth. Seaweeds can provide a dietary alternate owing to its nutritional assessment and its commercial worth can be superior by enlightening the superiority and escalating the range of seaweed-based products. Supplementary research is desirable to appraise the nutritional value of marine algae; seaweeds can be observed as an under-exploited source of health profit molecules for food dispensation and Nutraceutical industry.

\section{Conclusion}

The edible green, brown and red seaweeds, Caulerpa racemosa, Sargassum polycystum, Cystoseria myrica and Digenea simplex, were scrutinized for their nutritional compositions and were then compared to those in several other seaweeds and local vegetables. It absolutely initiate that the four seaweeds studied seemed to be fascinating probable sources of plant food proteins due to their high protein levels and balanced amino acid profiles. On the opposite hand the highest carbohydrate contents attained from the investigated species. they also showed the potential of being good sources of mineral supplements. The results of the current investigate clinched that these seaweeds will provide dietary alternatives owing to their nutritional values.

\section{Ethics}

The authors declare that they have no conflict of interest.

\section{References}

Cabrita, A.R.J., M.R.G. Maia, H.M. Oliveira, I. SousaPinto and A.A. Almeida et al., 2016. Tracing seaweeds as mineral sources for farm-animals. J. Applied Phycol., 28: 3135-3150.

DOI: $10.1007 / \mathrm{s} 10811-016-0839-y$

Cohen, Z., A. Vonshak and A. Richmond, 1988. Effect of environmental conditions on fatty acid composition of the red alga Porphyridium cruentum: Correlation to growth rate 1. J. Phycol., 24: 328-332.

DOI: 10.1111/j.1529-8817.1988.tb04474.x

Dhargalkar, V.K., T.G. Jagtap and A.G. Untawale, 1980. Biochemical constituents of seaweeds along the Maharashtra coast. Indian J. Mar. Sci., 9: 297-299.

Dubois, M., K.A. Gilles, J.K. Hamilton, P.A. Rebers and F. Smith, 1956. Colorimetric method for determination of sugars and related substances. Analytical Chem., 28: 350-356.

DOI: $10.1021 / \mathrm{ac} 60111 \mathrm{a} 017$

El Shafay, S.M, S.S. Ali and M.M. El-Sheekh, 2016. Antimicrobial activity of some seaweeds species from Red sea, against multidrug resistant bacteria. Egyptian J. Aquatic Res., 42: 65-74.

DOI: 10.1016/j.ejar.2015.11.006

El-Shafay, S.M., 2014. Biochemical composition of some seaweed from hurghada coastal along red sea coastal, Egypt. Int. J. Basic Applied Sci., 14: 29-35.

Evan, D. and R.F. Miller, 1978. Light-evoked potassium activity in mudpuppy retina: Its relationship to the b-wave of the electroretinogram. Brain Res., 154: 388-394. DOI: 10.1016/0006-8993(78)90711-4

Fan, X., L. Bai, L. Zhu, L. Yang and X. Zhang, 2014. Marine algae-derived bioactive peptides for human nutrition and health. J. Agric. Food Chem., 62: 9211-9222. DOI: 10.1021/jf502420h

Fleurence, J., M. Morançais and J. Dumay, 2018. Seaweed Proteins. In: Proteins in Food Processing, Yada, R.Y. (Ed.), Elsevier, ISBN-13: 978-0-08-100722-8 pp: 245-262: 
Folch, J., M. Lees and G.H. Sloane Stanley, 1957. A simple method for the isolation and purification of total lipides from animal tissues. J. Biol. Chem., 226: 497-509. PMID: 13428781

Galland-Irmouli, A.V., J. Fleurence, R. Lamghari, M. Luçon and C. Rouxel et al., 1999. Nutritional value of proteins from edible seaweed Palmaria palmata (Dulse). J. Nutrit. Biochem., 10: 353-359.

DOI: $10.1016 / \mathrm{S} 0955-2863(99) 00014-5$

Herbreteau, F, L.J.M. Coiffard, A. Derrien and Y. De Roeck-Holtzhauer, 1997. The fatty acid composition of five species of macroalgae. Botanica Marina, 40: 25-28. DOI: 10.1515/botm.1997.40.1-6.25

Hernández, I., J.A. Fernández and F.X. Niell, 1995. A comparative study of alkaline phosphatase activity in two species of Gelidium (Gelidiales, Rhodophyta). Eur. J. Phycol., 30: 69-77. DOI: 10.1080/09670269500650811

Ishakani, A.H., 2017. Amino acid and fatty acid composition of seaweeds (Ulva reticulata and Sargassum cinctum): A novel natural source of nutrition. Int. J. Pure Applied Biosci., 5: 1210-1216. DOI: $10.18782 / 2320-7051.5233$

Ismail, G.A., 2017. Biochemical composition of some Egyptian seaweeds with potent nutritive and antioxidant properties. Food Sci. Technol., 37: 294-302. DOI: 10.1590/1678-457x.20316

Ismail, M.M., G.M. El Zokm and A.A.M. El-Sayed, 2017. Variation in biochemical constituents and master elements in common seaweeds from Alexandria Coast, Egypt, with special reference to their antioxidant activity and potential food uses: Prospective equations. Environ. Monitor. Assess. 189: 648-648. DOI: 10.1007/s10661-017-6366-8

Ismail, M.M., S.F. Gheda and L. Pereira, 2016. Variation in bioactive compounds in some seaweeds from Abo Qir bay, Alexandria, Egypt. Rendiconti Lincei, 27: 269-279. DOI: 10.1007/s12210-015-0472-8

Ivanovitch, K., J. Klaewkla, R. Chongsuwat, C. Viwatwongkasem and W. Kitvorapat, 2014. The intake of energy and selected nutrients by Thai urban sedentary workers: an evaluation of adherence to dietary recommendations. J. Nutrit. Metabolism. DOI: $10.1155 / 2014 / 145182$

Janssen, J.H., J.L.S.P. Driessen, P.P. Lamers, R.H. Wijffels and M.J. Barbosa, 2018. Effect of initial biomass-specific photon supply rate on fatty acid accumulation in nitrogen depleted Nannochloropsis gaditana under simulated outdoor light conditions. Algal Res., 35: 595-601.

DOI: $10.1016 /$ j.algal.2018.10.002

John, R.P. and G.S. Anisha, 2011. Macroalgae and their potential for biofuel. CAB Rev., 6: 1-15.

DOI: $10.1079 /$ PAVSNNR20116038
Kolanjinathan, K. and P. Saranraj, 2014. Pharmacological efficacy of marine seaweed Gracilaria edulis extracts against clinical pathogens. Global J. Pharmacol., 8: 268-274.

Kolthoff, I.M., E.B. Sandell, E.J. Meehan and S. Bruckenstein, 1969. Quantitative chemical analysis. Macmillan, New York.

Li, B.W., K.W. Andrews and P.R. Pehrsson, 2002. Individual sugars, soluble and insoluble dietary fiber contents of 70 high consumption foods. J. Food Compos. Anal., 15: 715-723.

DOI: $10.1006 /$ jfca.2002.1096

Lowry, O.H., N.J. Rosebrough, A.L. Farr and R.J. Randall, 1951. Protein measurement with the Folin phenol reagent. J. Biol. Chem., 193: 265-275.

Lyu, Q., W. Jiao, K. Zhang, Z. Bao and S. Wang et al., 2016. Proteomic analysis of scallop hepatopancreatic extract provides insights into marine polysaccharide digestion. Scientific Rep., 6: 34866-34866. DOI: 10.1038/srep34866

MacArtain, P., C.I.R. Gill, M. Brooks, R. Campbell and I.R. Rowland, 2007. Nutritional value of edible seaweeds. Nutrit. Rev., 65: 535-543. DOI: 10.1111/j.1753-4887.2007.tb00278.x

Manivannan, K., G. Thirumaran, G. Karthikai Devi, P. Anantharaman and T. Balasubramanian, 2009. Proximate composition of different group of seaweeds from Vedalai Coastal waters (Gulf of Mannar): Southeast coast of India. Middle-East J. Scientific Res., 4: 72-77.

McBean, L.D. and E.W. Speckmann, 1988. Nutritive Value of Dairy Foods. In: Fundamentals of Dairy Chemistry, Wong, N.P., R. Jenness, M. Keeney and E.H. Marth (Eds.), Springer, Boston, pp: 343-407.

Nelson, M.M., C.F. Phleger and P.D. Nichols, 2002. Seasonal lipid composition in macroalgae of the northeastern Pacific Ocean. Botanica Marina, 45: 58-65. DOI: 10.1515/BOT.2002.007

Norziah, M.H. and C.Y. Ching, 2000. Nutritional composition of edible seaweed Gracilaria changgi. Food Chem., 68: 69-76.

DOI: 10.1016/S0308-8146(99)00161-2

Omar, H.H., B.M. Abdullatif, M.M. El-Kazan and A.M. El-Gendy, 2013. Red sea water and biochemical composition of seaweeds at Southern Coast of Jeddah, Saudi Arabia. Life Sci. J., 10: 1073-1080.

Ortiz, J., N. Romero, P. Robert, J. Araya and J. LopezHernández et al., 2006. Dietary fiber, amino acid, fatty acid and tocopherol contents of the edible seaweeds Ulva lactuca and Durvillaea antarctica. Food Chem., 99: 98-104.

DOI: 10.1016/j.foodchem.2005.07.027 
Peinado, I., J. Giŕn, G. Koutsidis and J.M. Ames, 2014. Chemical composition, antioxidant activity and sensory evaluation of five different species of brown edible seaweeds. Food Res. Int., 66: 36-44.

DOI: 10.1016/j.foodres.2014.08.035

Peng, Y., J. Hiu, B. Yang, X.P. Lin and X.F. Zhou et al., 2015. Chemical Composition of Seaweeds. In: Seaweed Sustainability: Food and Non-Food Applications, Tiwari, B.K. and D. Troy (Eds.), Elsevier, London, UK., pp: 79-124.

Qasim, R., 1991. Amino acid composition of some common seaweeds. Pak. J. Pharmaceutical Sci., 4: 49-54.

Ratana-Arporn, P. and A. Chirapart, 2006. Nutritional evaluation of tropical green seaweeds Caulerpa lentillifera and Ulva reticulata. Kasetsart J., 40: 75-83.

Rodríguez-Ruiz, J., E.H. Belarbi, J.L. García Sánchez and D.L. Alonso, 1998. Rapid simultaneous lipid extraction and transesterification for fatty acid analyses. Biotechnol. Techniques, 12: 689-691. DOI: 10.1023/A:1008812904017

Rupapara, K.V., 2017. Nutritive properties of the chorophyceae seaweeds available at Gulf of Kutch, Gujarat, India. Int. J. Pure Applied Biosci., 5: 174-179. DOI: 10.18782/2320-7051.2931

Sánchez-Machado, D.I., J. Ĺpez-Cervantes, J. LopezHernandez and P. Paseiro-Losada, 2004. Fatty acids, total lipid, protein and ash contents of processed edible seaweeds. Food Chem., 85: 439-444. DOI: $10.1016 /$ j.foodchem.2003.08.001

Sasikala, M., E. Indumathi, S. Radhika and R. Sasireka, 2016. Effect of seaweed extract (Sargassum tenerrimum) on seed germination and growth of tomato plant. Int. J. ChemTech Res., 9: 285-293.
Shanmugam, A. and C. Palpandi, 2008. Biochemical composition and fatty acid profile of the green alga Ulva reticulata. Asian J. Biochem., 3: 26-31. DOI: 10.3923/ajb.2008.26.31

Sobha, V., V.K. Bindu, M.S. Bindu and P. Unnikrishnan, 2001. Biochemical studies of algae along the southern Kerala coast with special reference to fibre content. Seaweed Res. Util., 23: 65-73.

Suddendorf, R.F., S.K. Wright and K.W. Boyer, 1981. Sampling procedure and determination of lead in canned foods. J. Assoc. Official Analytical Chem., 64: 657-660.

Telles, C.B.S., C. Mendes-Aguiar, G.P. Fidelis, A.P. Frasson and W.O. Pereira et al., 2018. Immunomodulatory effects and antimicrobial activity of heterofucans from Sargassum filipendula. J. Applied Phycol., 30: 569-578. DOI: $10.1007 / \mathrm{s} 10811-017-1218-\mathrm{z}$

Walker, S.K., J.L. Hill, D.O. Kleemann and C.D. Nancarrow, 1996. Development of ovine embryos in synthetic oviductal fluid containing amino acids at oviductal fluid concentrations. Biol. Reproduct., 55: 703-708. DOI: 10.1095/biolreprod55.3.703

Wong, K.H. and P.C.K. Cheung, 2000. Nutritional evaluation of some subtropical red and green seaweeds: Part I-proximate composition, amino acid profiles and some physico-chemical properties. Food Chem., 71: 475-482. DOI: $10.1016 / \mathrm{S} 0308-8146(00) 00175-8$

Zubia, M., S.G.A. Draisma, K.L. Morrissey, E. VarelaÁlvarez and O. De Clerck, 2019. Concise review of the genus Caulerpa JV Lamouroux. J. Applied Phycol. DOI: 10.1007/s10811-019-01868-9 